\title{
Comparison of the thrombophilic gene polymorphisms and recurrent pregnancy loss: Results on combined gene effect of FV Leiden, FVR2, FXIII, MTHFR(A1298C and C677T), PAI-1 4G/5G and ACE I/D genes in RPL Women from Minsk/Belarus and Canakkale - Sivas/Turkey
}

\author{
Fatma Silan $^{1}$, Irma Mosse ${ }^{2}$, Alexander Gonchar ${ }^{2}$, Nikita Sedlyar ${ }^{2}$, AlexanderV. Kilchevsky ${ }^{2}$, Onur Yildiz ${ }^{1}$, Banu Kuru ${ }^{1}$ and Ozturk Ozdemir ${ }^{1,3 *}$ \\ ${ }^{1}$ Department of Medical Genetics, Faculty of Medicine, Canakkale Onsekiz Mart University, Turkey \\ ${ }^{2}$ Institute of Genetics and Cytology at the National Academy of Sciences of Belarus, Republic of Belarus \\ ${ }^{3}$ Department of Medical Genetics, Faculty of Medicine, Cumhuriyet University, Turkey
}

\begin{abstract}
Aim: Recurrent pregnancy loss (RPL) is a serious fertility problem with polygenic multifactorial etiology. Thrombophilia plays an important role in RPL. We compare the combined effect of the thrombophilic gene mutations as: FVL, FactorVR2, MTHFRC677T, MTHFRA1298C, PAI-15G/4G, ACEI/D and FXIII103G>T on RPL women from two different Caucasian populations (Minsk/Belarus and Canakkale - Sivas/Turkey) was compared. This is the first report of thrombophilic mutations from South Slavic population of Belarusian.
\end{abstract}

Methods: 1590 RPL women (830 Turkish and 760 Belarussian) were evaluated and compared in the current results. Buccal smears (for Belarussian) and peripheral blood-EDTA (for Turkish) samples were used for DNA isolation. Reverse hybridization method (for Turkish) and Real time PCR (for Turkish and Belarusian populations) were used for genotyping.

Results: FVL, FVR2G/A, MTHFRA1298C are significantly frequent in Turkish RPL population than Belarusian cohort (p<0.001, p:0.002, p:0.0009 respectively) and $P A I-1$ 5G/4G, ACE I/D, FXIII103G/T mutations are significantly frequent in Belarusian RPL population than Turkish cohort (p:0.03, p:0.001, p<0.001 respectively). MTHFR 677T allele is frequent in both populations (0.32, 0.30, p:0.2) but homozygosity is more frequent in Turkish cohort significantly, this is probably because of the frequent consanguineous marriage. $A C E+P A I-1$ combination is the most frequent double mutations in both cohort. The triple $F V R 2+A C E I /$ $\mathrm{D}+F X I I I 103 \mathrm{G}>\mathrm{T}$ mutations were same in both populations.

Conclusion: Our results showed similar germ-line prothrombotic gene variations in RPL women in both populations, but the mutated FVL, FVR2G/A and MTHFRA1298G SNPs are significantly high in Turkish RPL women when compare to the Belarusian RPL women.

\section{Introduction}

Recurrent pregnancy loss (RPL) is defined if a couple having consecutive loss of two or more pregnancies with the same partner before 20 weeks of gestation and not more than one living child [14]. The RPL is a significant clinical problem with many etiologies. RPL is a complex process that a lots of molecular ethilogical factors may cause this dilemma but still large amount of cases are unidentified. Inherited and/or acquired thrombophilia is an important contributing factor in unexplained RPL [5-9]. RPL women are basicly classified into three groups as: women without previous 2 live birth, live birth after pregnancy losses, and pregnancy losses followed by a live birth [10]. Some RPL couples have an additional parental associated genetic risk factors but some have non-genetic histories [11,12]. In general, the RPL risk is enhanced by a variety of etiological factors such as; chromosomal abnormalities, uterine abnormalities, endocrinological defects, infections and environmental factors. Maternal, fetal, environmental and paternal based ethiological risk factors were also reported in RPL pathogenesis [13-15]. Thrombophilias have been postulated as a cause of RPL complications such as stillbirth, fetal growth restriction, severe preeclampsia, and placental abruption. Inherited and/or acquired thrombophilic gene polymorphisms are the basic debated problems that may common acceptable in women with unexplained RPL [14-16]. Recently, large amount of literature findings from different populations showed the incidence of specific thrombophilic gene polymorphisms in RPL women. Numereous studies have reported an association but some others have a lack of any association between thrombophilic gene mutations and RPL.

Correspondence to: Dr. Ozturk Ozdemir, Canakkale Onsekiz Mart University, Faculty of Medicine, Department of Medical Genetics, 17100, Canakkale, Turkey, Tel: +90 286 2180018/2107, E-mail: ozdemir615@yahoo.com

Key words: single nucleotide polymorphisms, factor $V$ leiden, genetic testing and counseling, population screening

Received: September 01, 2016; Accepted: September 26, 2016; Published: September 30, 2016 
Silan F (2016) Comparison of the thrombophilic gene polymorphisms and recurrent pregnancy loss: Results on combined gene effect of FV Leiden, FVR2, FXIII, MTHFR(A1298C and C677T), PAI-1 4G/5G and ACE I/D genes in RPL Women from Minsk/Belarus and Canakkale - Sivas/Turkey

In the current retrospective study we basically aimed to compare the trombophilic gene polymorphisms of FVLeiden(rs6025), FactorVR2(rs1800595), MTHFRC677T(rs1801133), MTHFRA1298C(rs1801131), PAI-15G/4G (rs1799889), ACEI/ $\mathrm{D}(\mathrm{rs} 4646994)$ and FXIII103G $>\mathrm{T}(\mathrm{rs} 5985)$ genes in RPL women from Minsk/Belarus and Canakkale - Sivas/Turkish populations.

\section{Materials and methods}

\section{Patients, clinical diagnosis and laboratory assessment}

Thrombophilic gene polymorphisms were correlated in two Caucasian populations in the current results (Minsk/Belarus and Canakkale - Sivas/Turkey). In a total of 1590 RPL women were enrolled between May 2007 - July 2015 retrospectively and eavluated. Results of the allelle frequencies and combined gene efficiency of target genes in RPL women were discussed. Eight hundred and thirty RPL women the mean age-min-max; $28.1 \pm 1.80$ (17-45) from Turkish and $760 \mathrm{RPL}$ women the mean age-min-max; $30 \pm 4.76(19-46)$ from Belarusian populations were evaluated. Peripheral blood-EDTA samples from each patient were used for germ-line target genes profiling. The results belong to the germ-line polymorphisms for target genes were compared for both populations.

\section{Genotyping}

The total genomic DNA was extracted by the MagnaPure Compact (Roche) and Invitek kit extraction techniques (Invitek; Invisorb spin blood, Berlin, Germany). Target genes were simultaneously amplified in a biotin-labelled single multiplex amplification reaction (Viennalab; PGX-HIV StripAssay, Vienna, Austria) which is based on the reverse-hybridization principle automatically and by Real Time PCR, LightCycler 2.0 methods (Roche). The multiple polymerase chain reaction (PCR) was performed in a Perkin Elmer 9600 and the profile consisted of an initial melting step of 2 min at $94^{\circ} \mathrm{C}$; followed by 35 cycles of $30 \mathrm{~s}$ at $94^{\circ} \mathrm{C}, 30 \mathrm{~s}$ at $61^{\circ} \mathrm{C}$, and $30 \mathrm{~s}$ at $72^{\circ} \mathrm{C}$; and a final elongation step of $7 \mathrm{~min}$ at $72^{\circ} \mathrm{C}$ for stripAssay genotyping. Some suspicious samples were clarified by real-time PCR technique (LightCycler 2.0, Roche).

All samples were genotyped for target genes in Turkish women with RPL history. Briefly, LightCycler FastStart DNA Master HybProbes, master mix and DNA template were used for real-time amplification. The amplification conditions for 45 cycles were; denaturation in $95^{\circ} \mathrm{C}$ for 10 seconds, annealing for $5-20$ seconds, extension in $72^{\circ} \mathrm{C}$, melting curve step with denaturation in $95^{\circ} \mathrm{C}$, annealing for 30 seconds, melting in $95^{\circ} \mathrm{C}$ and cooling step in $40^{\circ} \mathrm{C}$ for 30 seconds. Software programme (LightCycler 2.0, Roche) was used for detection of the mutated and normal genotype profiles of target genes in the current RPL women (Figures 1 and 2).

The total genomic DNA was extracted from buccal swabs (nucleosorb A extraction kit, Primetech, Minsk, Belarusian) for the current RPL cohort from Belarusian population. The quantities of all DNA samples were measured by using dsDNA Assay Kit, BroadRange for Qubit ${ }^{\oplus}$ Fluorometer from Invitrogen and multiplex Real-time PCR was performed in a CFX 96 (Bio-rad, US) using 96-well plates for target genes genotyping.

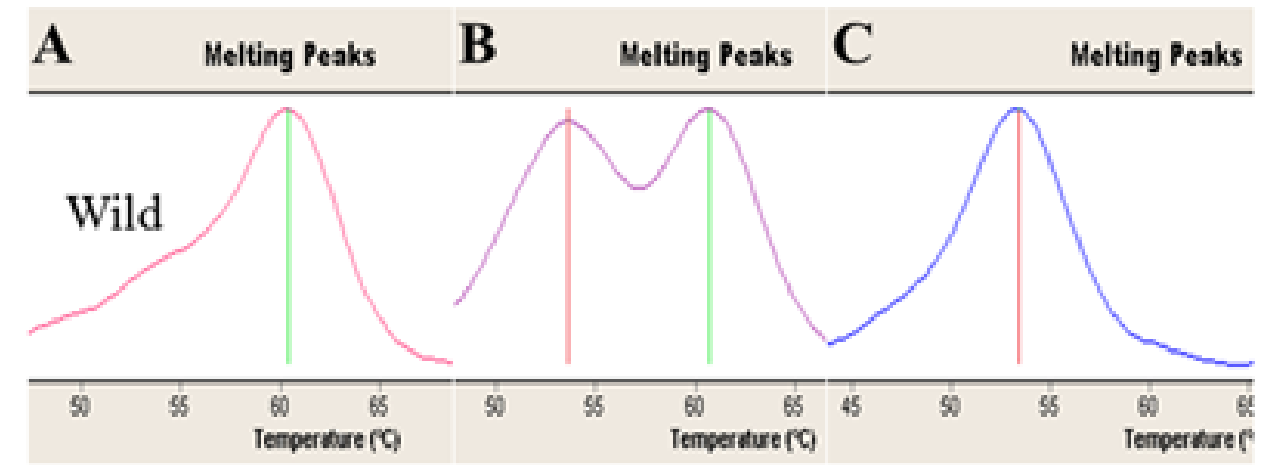

Figure 1. Shows the Real Time-PCR melting peaks profiles for $P A I-1$ genotypes that evaluated for the current RPL women. A. Homozygous $5 \mathrm{G} / 5 \mathrm{G}$ genotype (Tm: $\left.61^{\circ} \mathrm{C}\right)$, B. Heterozygous $5 \mathrm{G} / 4 \mathrm{G}$ genotype $\left(\mathrm{Tm}: 61^{\circ} \mathrm{C}\right.$ and $\left.54^{\circ} \mathrm{C}\right), \mathrm{C}$. Homozygous $4 \mathrm{G} / 4 \mathrm{G}$ genotype $\left(\mathrm{Tm}: 54^{\circ} \mathrm{C}\right)$.

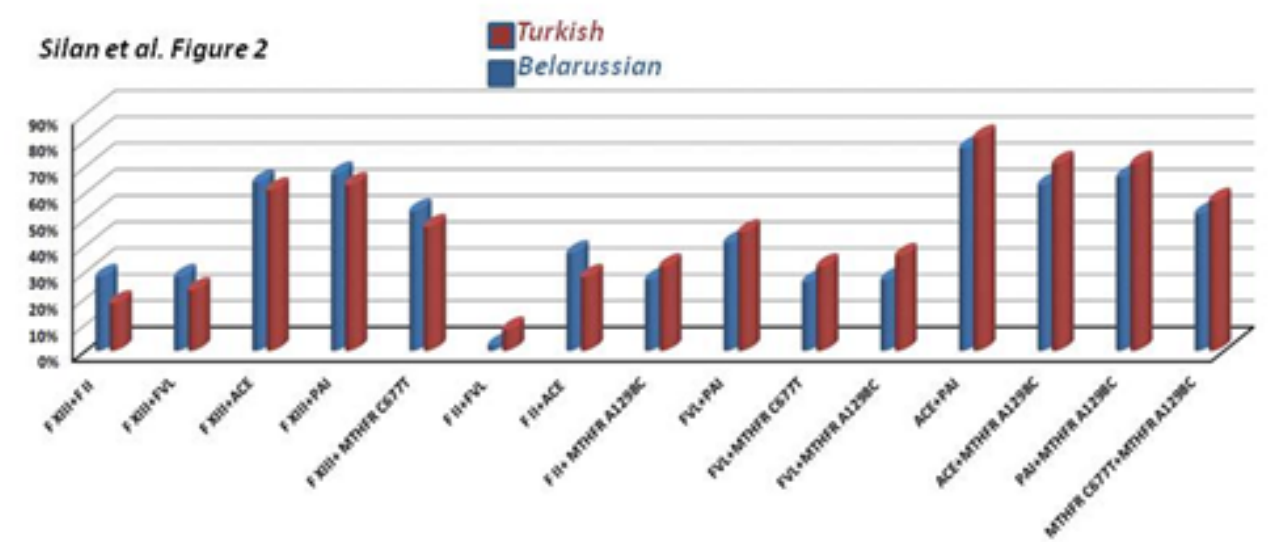

Figure 2. Frequencies of being dual homozygous and heterozygous combined mutations for some target genes in RPL women from Turkish and Belarussion populations. No significant difference was noted in thrombophilic gene mutations in the current Caucasian population cohorts. 
Silan F (2016) Comparison of the thrombophilic gene polymorphisms and recurrent pregnancy loss: Results on combined gene effect of FV Leiden, FVR2, FXIII, MTHFR(A1298C and C677T), PAI-1 4G/5G and ACE I/D genes in RPL Women from Minsk/Belarus and Canakkale - Sivas/Turkey

The PCR reactions were performed in a total volume of $10 \mu \mathrm{L}$ with a reaction mixture containing $300 \mathrm{nM}$ of each primer, 2XiTaq Universal probes supermix (Bio-rad, US), $50 \mathrm{nM}$ probes, and $15 \mathrm{ng}$ of template DNA samples. The taqman probes, master mix that contains forward and reverse primer sequences for target genes and DNA template were used for Real-Time amplification. Briefly, the amplification conditions for 40 cycles were; denaturation in $95^{\circ} \mathrm{C}$ for $5 \mathrm{~min}$, annealing for 5-20 seconds, extension in $60^{\circ} \mathrm{C}$ for $5-20$ seconds.

\section{Statistical analysis}

Alternative genotype frequencies for mutated target gene markers in RPL women from both populations were compared using Pearson's chi-square test and multiple logistic regression analysis. Statistical analysis was performed using SPSS version 15 (SPSS, Chicago, IL, USA). Values of $\mathrm{P}<0.05$ were considered statistically significant and mutated allele frequencies were discussed in the current report.

\section{Results}

Results from peripheral blood-EDTA and buccal smear samples from Turkish and Belarussian RPL women that were genotyped for thrombophila genes were enrolled and compared for the current study retrospectively. Eight hundred and thirty RPL women the mean agemin-max; $28.1 \pm 1.80(17-45)$ from Turkish and 760 RPL women the mean age-min-max; $30 \pm 4.76(19-46)$ from Belarusian populations were evaluated. The average pregnancy losses were 2.7(1-10) for Turkish and 2.0(1-7) for the Belarusian RPL women cohorts (Table 1). The estimate risk was examined by odds ratio. Retrospectively evaluated results showed similar germ-line variations for target studied genes in RPL women in both populations.

The distribution of genotype frequencies of the studied polymorphisms between the current RPL women form both populations were in Hardy-Weinberg equilibrium and no statistically significant differences was found in terms of the age and gender. The both germ-line $\mathrm{T}$ and $\mathrm{C}$ alleles frequencies of MTHFR $677 \mathrm{C}>\mathrm{T}$ and 1298 A $>$ C SNPs have been shown to be a risk factor for the current cohort RPL women for both populations (Table 2). The prevalence of genotypes of MTHFR gene C677T SNP in Turkish RPL women $(48 \%$ for CC, $40 \%$ for CT and $12 \%$ for TT respectively) were the similar as Belarusian RPL cohort (48.29\% for CC, $43.16 \%$ for CT and $8.55 \%$ for TT) respectively, (Table 2). The T allele frequency were 0.320 for the Turkish and 0.301 for the Belarusian RPL women. No statistical significance detected between allel frequencies (Table 2), (OR: 1.0936, CI: 0.9409-1.2711), $\mathrm{p}<0.2437$ ) but the MTHFR 677TT (homozygous) genotype were significantly higher in Turkish cohort (12.0\%) when

Table 1. Some clinical characteristics for studied cohort of RPL women from Turkish and Belarussian populations.

\begin{tabular}{|l|l|l|}
\hline Clinical Characteristics & Population & \multicolumn{2}{l|}{} \\
\cline { 2 - 3 } & Turkish & Belarussian \\
\hline Patients (n) & $\begin{array}{l}\text { RPL Women } \\
\text { n:830 }\end{array}$ & $\begin{array}{l}\text { RPL Women } \\
\text { n:760 }\end{array}$ \\
\hline Biological Material(n/\%) & $\begin{array}{l}\text { Peripheral Blood- } \\
\text { EDTA } \\
(830 / 100)\end{array}$ & $\begin{array}{l}\text { Buccal Smear } \\
(760 / 100)\end{array}$ \\
\hline $\begin{array}{l}\text { Age(year), Median } \pm \text { S. D. (range) } \\
\text { No of pregnancy losses Median } \\
\text { (range) }\end{array}$ & $28.1 \pm 1.80(17-45)$ & $30 \pm 4.76(19-46)$ \\
\hline No of live births Median (range) & 0 & $2.0(1-7)$ \\
\hline
\end{tabular}

RPL: Recurrent pregnancy loss
Table 2. The Genotype and Allele Frequency of MTHFR C677T and MTHFR A1298C SNPs in RPL women for both populations.

\begin{tabular}{|c|c|c|c|}
\hline \multicolumn{2}{|l|}{ Patient Group (n) } & \multicolumn{2}{|l|}{ Population } \\
\hline & & Turkish & \multirow{2}{*}{\begin{tabular}{|l|} 
Belarussian \\
$\begin{array}{l}\text { RPL Women } \\
(\mathrm{n}: 760)\end{array}$ \\
\end{tabular}} \\
\hline & & $\begin{array}{l}\text { RPL Women } \\
\text { (n:830) }\end{array}$ & \\
\hline \multicolumn{2}{|l|}{ Gene/SNP } & \multirow[t]{2}{*}{ MTHFR C677T } & MTHFR C677T \\
\hline \multicolumn{2}{|l|}{ Genotypes (n/\% ) } & & \\
\hline \multicolumn{2}{|l|}{$\mathrm{CC}$} & $398 / 48.0$ & $367 / 48.29$ \\
\hline \multicolumn{2}{|l|}{$\mathrm{CT}$} & $332 / 40.0$ & $328 / 43.16$ \\
\hline \multicolumn{2}{|l|}{ TT } & $100 / 12.0$ & $65 / 8.55$ \\
\hline \multicolumn{4}{|l|}{ Alleles } \\
\hline \multicolumn{2}{|l|}{$\mathrm{C}$} & $1128 / 0.680$ & $1062 / 0.699$ \\
\hline \multicolumn{2}{|l|}{$\mathrm{T}$} & $532 / 0.320$ & $458 / 0.301$ \\
\hline \multicolumn{4}{|c|}{ Statistically Analysis } \\
\hline \multirow{3}{*}{ Recessive Model } & P Value & \multicolumn{2}{|l|}{$\mathrm{P}=0.0230$} \\
\hline & OR & \multicolumn{2}{|l|}{1.4647} \\
\hline & $\mathrm{CI}(95 \%)$ & \multicolumn{2}{|l|}{$1.0540-2.0355$} \\
\hline \multirow{3}{*}{ Dominant Model } & P Value & \multicolumn{2}{|l|}{$\mathrm{P}=0.8929$} \\
\hline & OR & \multicolumn{2}{|l|}{1.0136} \\
\hline & $\mathrm{CI}(95 \%)$ & \multicolumn{2}{|l|}{$0.8324-1.2343$} \\
\hline \multirow{3}{*}{ Allel Frequencies } & P Value & \multicolumn{2}{|l|}{$\mathrm{P}=0.2437$} \\
\hline & OR & \multicolumn{2}{|l|}{1.0936} \\
\hline & $\mathrm{CI}(95 \%)$ & \multicolumn{2}{|l|}{$0.9409-1.2711$} \\
\hline Gene/SNP & & MTHFR A1298C & MTHFR A1298C \\
\hline & & $(\mathrm{n}: 772)$ & $(\mathrm{n}: 760)$ \\
\hline Genotypes (n/\% ) & & & \\
\hline AA & & $289 / 37.44$ & $355 / 46.72$ \\
\hline $\mathrm{AC}$ & & $376 / 48.70$ & $323 / 42.50$ \\
\hline $\mathrm{CC}$ & & $107 / 13.86$ & $82 / 10.78$ \\
\hline Alleles & & & \\
\hline A & & $972 / 0.618$ & $1033 / 0.680$ \\
\hline $\mathrm{C}$ & & $590 / 0.382$ & $487 / 0.320$ \\
\hline Statistically Analy & & & \\
\hline & P Value & $\mathrm{P}=0.0683$ & \\
\hline Recessive Model & OR & 1.3304 & \\
\hline & $\mathrm{CI}(95 \%)$ & $0.9788-1.8083$ & \\
\hline & P Value & $\mathrm{P}=0.0002$ & \\
\hline Dominant Model & OR & 1.4649 & \\
\hline & $\mathrm{CI}(95 \%)$ & $1.1948-1.7962$ & \\
\hline & P Value & $\mathrm{P}=0.0009$ & \\
\hline Allele Frequency & OR & 1.2875 & \\
\hline & $\mathrm{CI}(95 \%)$ & $1.1098-1.4937$ & \\
\hline
\end{tabular}

compare to the Belarusian cohort (8.55\%) (p:0.023).

Significant difference was detected in the second SNP marker (A1298C) of MTHFR gene in Turkish (37.44\% for AA, 48.70\% for AC and $13.86 \%$ for CC respectively) and Belarusian RPL women (46.72\% for AA, $42.5 \%$ for AC and $10.78 \%$ for CC) respectively, (Table 2). The $\mathrm{C}$ allele frequency was 0.382 for Turkish and 0.320 for Belarusian RPL women. The MTHFR 1298 A $>$ C SNP (homozygous) genotype was found $13.86 \%$ for Turkish and $10.78 \%$ for the Belarusian cohorts (Table 2), (OR: 1.2875, CI: 1.1098-1.4937), p<0.0009.

The prevalence of genotypes of $P A I-15 \mathrm{G} / 4 \mathrm{G}$ gene in Turkish RPL women $(20.63 \%$ for $5 \mathrm{G} / 5 \mathrm{G}, 56.33 \%$ for $5 \mathrm{G} / 4 \mathrm{G}$ and $23.04 \%$ for $4 \mathrm{G} / 4 \mathrm{G})$, respectively was the similar as in Belarusian group $(20.0 \%$ for $5 \mathrm{G} / 5 \mathrm{G}, 50.0 \%$ for $5 \mathrm{G} / 4 \mathrm{G}$ and $30.0 \%$ for $4 \mathrm{G} / 4 \mathrm{G}$ ), (Table 3 ). The $4 \mathrm{G}$ allele frequency was 0.513 for the Turkish and 0.550 for the Belarusian cohort. The PAI-14G/4G gene (homozygous) genotype was found 23.04\% in Turkish and 30.0\% in Belarusian RPL women and difference 
Silan F (2016) Comparison of the thrombophilic gene polymorphisms and recurrent pregnancy loss: Results on combined gene effect of FV Leiden, FVR2, FXIII, MTHFR(A1298C and C677T), PAI-1 4G/5G and ACE I/D genes in RPL Women from Minsk/Belarus and Canakkale - Sivas/Turkey

was statistically significant (Table 3), (OR: 1.1648, CI: 1.0114-1.3415), $\mathrm{p}<0.0342)$.

The prevalence of genotypes of $A C E \mathrm{I} / \mathrm{D}$ in Turkish RPL group (35.47\% for D/D $48.26 \%$ for $\mathrm{I} / \mathrm{D}$ and $16.27 \%$ for $\mathrm{I} / \mathrm{I})$ and $(23.94 \%$ for $\mathrm{D} / \mathrm{D} 50.14 \%$ for $\mathrm{I} / \mathrm{D}$ and $25.92 \%$ for $\mathrm{I} / \mathrm{I}$ ) in Belarusian group respectively (Table 4 ). The I allele frequency was 0.404 for Turkish and 0.510 for the Belarusian groups. The ACE I/I (homozygous) genotype was found $16.27 \%$ and $25.92 \%$ in Turkish and Belarusian RPL women respectivelly. The mutated I allele frequency was different and that difference was statistically significant (Table 4), (OR: $1.5342, \mathrm{CI}$ : $1.3075-1.8003), \mathrm{p}<0.0001$.

The prevalence for genotypes of FVLG/A gene were $(87.23 \%$ for $\mathrm{G} / \mathrm{G} 12.41 \%$ for $\mathrm{G} / \mathrm{A}$ and $0.36 \%$ for $\mathrm{A} / \mathrm{A}$ ) and $(97.89 \%$ for $\mathrm{G} / \mathrm{G}$

Table 3. The Genotype and Allele Frequency of PAI-1 5G/4G gene polymorphisms in studied RPL women for the current results.

\begin{tabular}{|c|c|c|c|}
\hline & \multicolumn{2}{|l|}{ Population } \\
\hline \multirow{2}{*}{\multicolumn{2}{|c|}{ Patient Group (n) }} & Turkish & Belarussian \\
\hline & & $\begin{array}{l}\text { RPL Women } \\
\text { (n:790) }\end{array}$ & $\begin{array}{l}\text { RPL Women } \\
\text { (n:760) }\end{array}$ \\
\hline \multicolumn{2}{|l|}{ Gene/SNP } & PAI-1 5G/4G & $P A I-1$ 5G/4G \\
\hline \multicolumn{4}{|l|}{ Genotypes (n/\% ) } \\
\hline \multicolumn{2}{|l|}{$5 \mathrm{G} / 5 \mathrm{G}$} & $163 / 20.63$ & $152 / 20.00$ \\
\hline \multicolumn{2}{|l|}{$5 \mathrm{G} / 4 \mathrm{G}$} & $445 / 56.33$ & $380 / 50.00$ \\
\hline \multicolumn{2}{|l|}{$4 \mathrm{G} / 4 \mathrm{G}$} & $182 / 23.04$ & $228 / 30.00$ \\
\hline \multicolumn{4}{|l|}{ Alleles } \\
\hline \multicolumn{2}{|l|}{$5 \mathrm{G}$} & $771 / 0.487$ & $684 / 0.450$ \\
\hline \multicolumn{2}{|l|}{$4 \mathrm{G}$} & $809 / 0.513$ & $836 / 0.550$ \\
\hline \multirow[t]{3}{*}{ Recessive Model } & P Value & \multicolumn{2}{|l|}{$\mathrm{P}=0.0019$} \\
\hline & OR & \multicolumn{2}{|l|}{1.4317} \\
\hline & $\mathrm{CI}(95 \%)$ & \multicolumn{2}{|l|}{$1.1410-1.7964$} \\
\hline \multirow[t]{3}{*}{ Dominant Model } & P Value & \multicolumn{2}{|l|}{$\mathrm{P}=0.7569$} \\
\hline & OR & \multicolumn{2}{|l|}{0.9617} \\
\hline & $\mathrm{CI}(95 \%)$ & \multicolumn{2}{|l|}{$0.7508-1.2318$} \\
\hline \multirow[t]{3}{*}{ Allele Frequency } & P Value & \multicolumn{2}{|l|}{$\mathrm{P}=0.0342$} \\
\hline & OR & \multicolumn{2}{|l|}{1.1648} \\
\hline & $\mathrm{CI}(95 \%)$ & \multicolumn{2}{|l|}{$1.0114-1.3415$} \\
\hline
\end{tabular}

Table 4. The Genotype and Allele Frequency of $A C E$ I/D gene polymorphisms in RPL and control individuals from both populations.

\begin{tabular}{|c|c|c|c|}
\hline & \multicolumn{2}{|l|}{ Population } \\
\hline \multirow{2}{*}{\multicolumn{2}{|c|}{ Patient Group (n) }} & Turkish & Belarussian \\
\hline & & $\begin{array}{l}\text { RPL Women } \\
\text { (n:516) }\end{array}$ & $\begin{array}{l}\text { RPL Women } \\
\text { (n:760) }\end{array}$ \\
\hline \multicolumn{2}{|l|}{ Gene/SNP } & $A C E \mathbf{I} / \mathrm{D}$ & $A C E \mathrm{I} / \mathrm{D}$ \\
\hline \multicolumn{4}{|l|}{ Genotypes (n/\% ) } \\
\hline \multicolumn{2}{|l|}{$\mathrm{D} / \mathrm{D}$} & $183 / 35.47$ & $182 / 23.94$ \\
\hline \multicolumn{2}{|l|}{$\mathrm{D} / \mathrm{I}$} & $249 / 48.26$ & $381 / 50.14$ \\
\hline \multicolumn{2}{|l|}{$\mathrm{I} / \mathrm{I}$} & $84 / 16.27$ & $197 / 25.92$ \\
\hline \multicolumn{4}{|l|}{ Alleles } \\
\hline \multicolumn{2}{|l|}{$\mathrm{D}$} & $615 / 0.596$ & $745 / 0.490$ \\
\hline \multicolumn{2}{|l|}{ I } & $417 / 0.404$ & $775 / 0.510$ \\
\hline \multirow[t]{3}{*}{ Recessive Model } & P Value & \multicolumn{2}{|l|}{$P=0.0001 *$} \\
\hline & OR & \multicolumn{2}{|l|}{1.7995} \\
\hline & $\mathrm{CI}(95 \%)$ & \multicolumn{2}{|l|}{$1.3539-2.3918$} \\
\hline \multirow[t]{3}{*}{ Dominant Model } & P Value & \multicolumn{2}{|l|}{$\mathbf{P}<0.0001 *$} \\
\hline & OR & \multicolumn{2}{|l|}{1.7453} \\
\hline & $\mathrm{CI}(95 \%)$ & \multicolumn{2}{|l|}{$1.3653-2.2310$} \\
\hline \multirow[t]{3}{*}{ Allel Frequencies } & P Value & \multicolumn{2}{|l|}{$\mathrm{P}<0.0001^{*}$} \\
\hline & OR & \multicolumn{2}{|l|}{1.5342} \\
\hline & $\mathrm{CI}(95 \%)$ & \multicolumn{2}{|l|}{$1.3075-1.8003$} \\
\hline
\end{tabular}

*: Significant
2.11\% for G/A and $0.0 \%$ for A/A) for Turkish and Belarussian groups respectively (Table 5). The A allele frequency was 0.066 for Turkish and 0.011 for the Belarusian groups. The FVLA/A (homozygous) genotype was found $0.36 \%$ and $0.00 \%$ in Turkish and Belarusian RPL women respectivelly. Mutated A allele frequency was lower in Belarusian patients and that difference was statistically significant (Table 5), (OR: 6.6061, CI: 3.8903-11.2177), p<0.0001. Statistically significant difference was also detected in FVR2 G/A SNP in the studied populations in the current results. The prevalence of genotypes of FVR2G/A in Turkish RPL group ( $94.82 \%$ for G/G $4.94 \%$ for G/A and $0.24 \%$ for $\mathrm{A} / \mathrm{A}$ ) and (98.29\% for G/G $1.71 \%$ for $\mathrm{G} / \mathrm{A}$ and $0.0 \%$ for $\mathrm{A} / \mathrm{A}$ ) in Belarusian group respectively (Table 6). The A allele frequency was 0.027 for Turkish and 0.009 for the Belarusian groups. The FVR2A/A (homozygous) genotype was found $0.24 \%$ and $0.00 \%$ in Turkish and Belarusian RPL women respectively. Mutated A allele frequency was lower in Belarusian patients and that difference was statistically significant (Table 6), (OR: 3.2301, CI: 1.7356-6.0112), $\mathrm{p}<0.0002$.

Increased frequency of mutated Factor FXIII103G $>\mathrm{T}$ gene was detected in Belarusian RPL cohort in the current results. That difference was also statistically significant when comapred to Turkish RPL cohort. The prevalence of genotypes for FXIII103G $>\mathrm{T}$ in Turkish RPL group $(59.89 \%$ for G/G, $38.37 \%$ for G/T and $1.74 \%$ for $\mathrm{T} / \mathrm{T}$ ) and $(45.00 \%$ for $\mathrm{G} / \mathrm{G}, 45.79 \%$ for $\mathrm{G} / \mathrm{T}$ and $9.21 \%$ for $\mathrm{T} / \mathrm{T})$ in Belarusian group respectively (Table 7). The Leucine aminoasid frequency was 0.209 for Turkish and 0.321 for the Belarusian groups. The FXIII103G>T (homozygous) genotype was found $1.74 \%$ and 9.21\% in Turkish and Belarusian RPL women respectivelly. Lecuine frequency was 5.29-fold increased in the Belarusian patients, difference was statistically significant (Table 7), (OR: 1.7864, CI: 1.4852-2.1486), $\mathrm{p}<0.0001$.

The double and triple combined gene mutations profiles were also compared in the current RPL cohorts. Bar graphs in Figure 2 and 3 shows the frequencies of being dual and triple homozygous and/or heterozygous combined mutations for the target thrombophilic genes in RPL women from Turkish and Belarusian populations. ACE $+M T H F R$

Table 5. The Genotype and Allele Frequency of $F V L$ G/A gene polymorphisms in RPL women from both populations

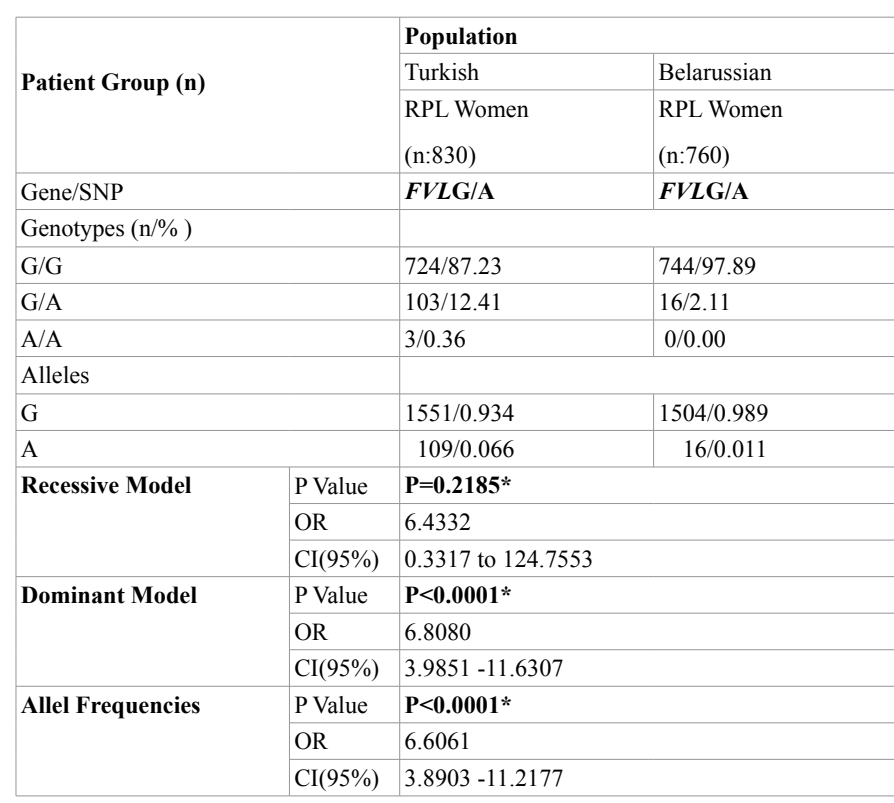

*: Significant 
Silan F (2016) Comparison of the thrombophilic gene polymorphisms and recurrent pregnancy loss: Results on combined gene effect of FV Leiden, FVR2, FXIII, MTHFR(A1298C and C677T), PAI-1 4G/5G and ACE I/D genes in RPL Women from Minsk/Belarus and Canakkale - Sivas/Turkey

Table 6. The Genotype and Allele Frequency of FVR2G/A gene polymorphisms in RPL women from both populations.

\begin{tabular}{|c|c|c|c|}
\hline \multirow[b]{3}{*}{ Patient Group (n) } & & \multicolumn{2}{|l|}{ Population } \\
\hline & & Turkish & Belarussian \\
\hline & & $\begin{array}{l}\text { RPL Women } \\
(\mathrm{n}: 830)\end{array}$ & $\begin{array}{l}\text { RPL Women } \\
(\mathrm{n}: 760)\end{array}$ \\
\hline \multicolumn{2}{|l|}{ Gene/SNP } & FVR2G/A & FVR2G/A \\
\hline \multicolumn{4}{|l|}{ Genotypes (n/\% ) } \\
\hline \multicolumn{2}{|l|}{$\mathrm{G} / \mathrm{G}$} & $787 / 94.82$ & 747/98.29 \\
\hline \multicolumn{2}{|l|}{ G/A } & $41 / 4.94$ & $13 / 1.71$ \\
\hline \multicolumn{2}{|l|}{$\mathrm{A} / \mathrm{A}$} & $2 / 0.24$ & $0 / 0.00$ \\
\hline \multicolumn{4}{|l|}{ Alleles } \\
\hline \multicolumn{2}{|l|}{ G } & $1615 / 0.973$ & $1507 / 0.991$ \\
\hline \multicolumn{2}{|l|}{ A } & $45 / 0.027$ & $13 / 0.009$ \\
\hline \multirow{3}{*}{ Recessive Model } & P Value & \multicolumn{2}{|l|}{$\mathrm{P}=0.3256^{*}$} \\
\hline & OR & \multicolumn{2}{|l|}{4.5896} \\
\hline & $\mathrm{CI}(95 \%)$ & \multicolumn{2}{|l|}{$0.2200-95.7567$} \\
\hline \multirow{3}{*}{ Dominant Model } & P Value & \multicolumn{2}{|l|}{$P=0.0004 *$} \\
\hline & OR & \multicolumn{2}{|l|}{3.1396} \\
\hline & $\mathrm{CI}(95 \%)$ & \multicolumn{2}{|l|}{$1.6748-5.8854$} \\
\hline \multirow{3}{*}{ Allel Frequencies } & P Value & \multicolumn{2}{|l|}{$\mathrm{P}=0.0002 *$} \\
\hline & OR & \multicolumn{2}{|l|}{3.2301} \\
\hline & $\mathrm{CI}(95 \%)$ & \multicolumn{2}{|l|}{$1.7356-6.0112$} \\
\hline
\end{tabular}

*:Significant

Table 7. The Genotype and Allele Frequency of $F$ XIII $103 G>T$ gene polymorphisms in RPL women from both populations

\begin{tabular}{|c|c|c|c|}
\hline \multirow[b]{3}{*}{ Patient Group (n) } & & \multicolumn{2}{|l|}{ Population } \\
\hline & & Turkish & Belarussian \\
\hline & & $\begin{array}{l}\text { RPL Women } \\
(\mathrm{n}: 516)\end{array}$ & $\begin{array}{l}\text { RPL Women } \\
(n: 760)\end{array}$ \\
\hline Gene/SNP & & FXIIII103G $>$ T & FXIII103G $>$ T \\
\hline \multicolumn{4}{|l|}{ Genotypes (n/\% ) } \\
\hline \multicolumn{2}{|l|}{$\mathrm{G} / \mathrm{G}$} & $309 / 59.89$ & $342 / 45.00$ \\
\hline \multicolumn{2}{|l|}{$\mathrm{G} / \mathrm{T}$} & $198 / 38.37$ & $348 / 45.79$ \\
\hline \multicolumn{2}{|l|}{$\mathrm{T} / \mathrm{T}$} & $9 / 1.74$ & $70 / 9.21$ \\
\hline \multicolumn{4}{|l|}{ Alleles } \\
\hline \multicolumn{2}{|l|}{ G } & $816 / 0.791$ & $1032 / 0.679$ \\
\hline \multicolumn{2}{|l|}{$\mathrm{T}$} & $216 / 0.209$ & $488 / 0.321$ \\
\hline \multirow{3}{*}{ Recessive Model } & P Value & \multicolumn{2}{|l|}{$P<0.0001 *$} \\
\hline & OR & \multicolumn{2}{|l|}{5.7150} \\
\hline & $\mathrm{CI}(95 \%)$ & \multicolumn{2}{|l|}{$2.8281-11.5485$} \\
\hline \multirow{3}{*}{ Dominant Model } & P Value & \multicolumn{2}{|l|}{$\mathrm{P}<0.0001 *$} \\
\hline & OR & \multicolumn{2}{|l|}{1.8245} \\
\hline & $\mathrm{CI}(95 \%)$ & \multicolumn{2}{|l|}{$1.4543-2.2888$} \\
\hline \multirow{3}{*}{ Allel Frequencies } & P Value & \multicolumn{2}{|l|}{$P<0.0001 *$} \\
\hline & OR & \multicolumn{2}{|l|}{1.7864} \\
\hline & $\mathrm{CI}(95 \%)$ & \multicolumn{2}{|l|}{$1.4852-2.1486$} \\
\hline
\end{tabular}

A1298C, PAI-1+MTHFRA1298C, MTHFRC677T+MTHFRA1298C, FXIII+MTHFRC677T and FXIII+PAI-1 double combined mutations are common in both populations. The higest double combined mutations were detected in ACE+PAI-1 genes in both RPL cohort (Figure 2). The triple FVR2+ACEI/D+FXIII mutations were totaly the same in both populations (Figure 3 ). The higest triple combined mutations were detected in FVL+MTHFRA1298C $+P A I-1$, FVL $+M T H F R A 1298 \mathrm{C}+A C E, \quad F V R 2+A C E+P A I-1$ and FXIII+ $F V R 2+P A I-1$ genes respectivelly. The lowest triple combined mutations was detected in FXIII+FII+FVL gene combinations (Figure 3).

\section{Discussion}

Two Caucasian populations were basically compared for thrombophila genes in RPL dilemma in the current results. Here is the first report for the thrombophilic gene mutations in South Slavic Belarusian population. The common polymorphic genes of FVLeiden, FVR2, FXIII, MTHFR(A1298C and C677T), PAI-14G/5G and ACEI/D were compared for two populations. The presented retrospective results from peripheral blood-EDTA and buccal smear samples from Turkish and Belarussian RPL women showed the similar/strong association between RPL and thrombophilia.

The distribution of genotype frequencies of the studied polymorphisms between the current RPL women form both populations were in Hardy-Weinberg equilibrium and no statistically significant differences was found in terms of the age and gender. The studied FVL, FVR2, MTHFR mutations were frequently observed in Turkish cohort and ACE, PAI1 and FXIII were frequent mutations in Belarusian cohort.

Trombophilic factors may have an important role in influencing the pregnancy outcome. Incompatible literature findings showed the possible relation between RPL and thrombophilia genes. Some showed significant association [15-19] and some other showed no significance [20,21]. Pregnancy losses due to de novo chromosomal aneuploidies occur at similar frequencies in some populations. Some RPL couples have additional associated genetic factors such as thrombophilic mutated genes and some have non-genetic etiologies. Qiao et al. have claimed that the compound heterozygous deleterious mutations affecting DYNC2H1 and ALOX15 genes may contribute to the pathogenesis of RPL after whole exome sequencing in couples with pregnancy loss [22]. A single nucleotide polymorphism (SNP) in codons C677T and A1298C of the MTHFR gene causes a thermolabile enzyme with reduced function and defects in DNA hypomethylation.

\section{Silan et al. Figure 3}

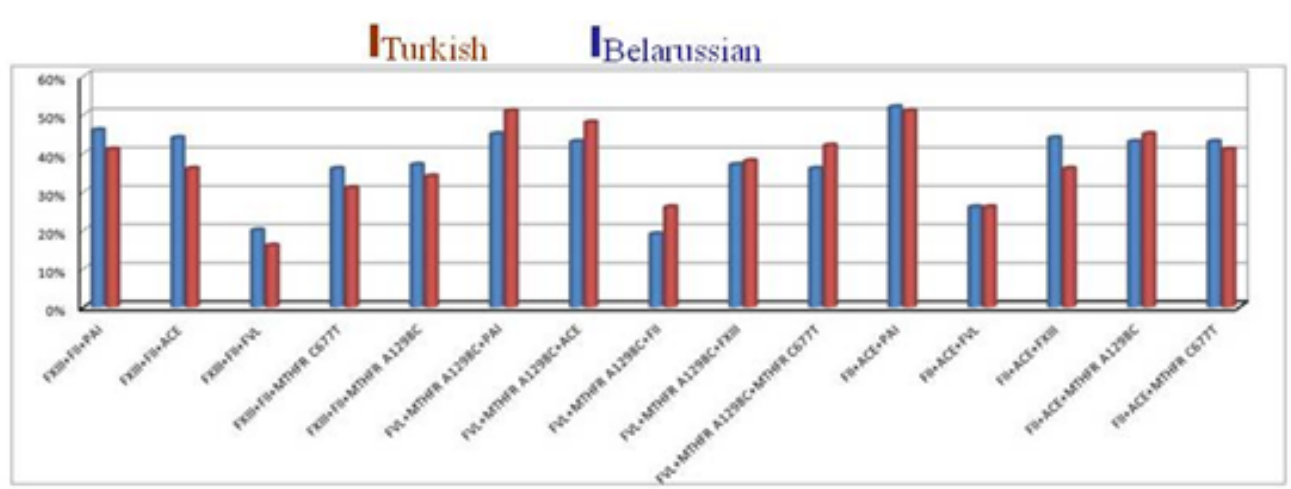

Figure 3. Shows the frequencies of being triple homozygous and heterozygous combined mutations for some target genes in RPL women from Turkish and Belarussion populations. No significant difference was noted in thrombophilic gene mutations in the current Caucasian population cohorts. 
Silan F (2016) Comparison of the thrombophilic gene polymorphisms and recurrent pregnancy loss: Results on combined gene effect of FV Leiden, FVR2, FXIII, MTHFR(A1298C and C677T), PAI-1 4G/5G and ACE I/D genes in RPL Women from Minsk/Belarus and Canakkale - Sivas/Turkey

Naushad et al have claimed that the MTHFR C677T polymorphism influences the RPL complications such as; hyperhomocysteinemia and its associated complications of RPL, NTDs, DVT, MI anf POF [23,24].

The both germ-line $\mathrm{T}$ and $\mathrm{C}$ alleles frequencies of MTHFR 677 $\mathrm{C}>\mathrm{T}$ and $1298 \mathrm{~A}>\mathrm{C}$ SNPs have been shown to be a risk factors for the current cohort RPL women from Turkish and Belarusian populations. The mutated $\mathrm{T}$ allele frequencies were similar as 0.382 for the Turkish and 0.320 for the Belarusian RPL women cohorts but homozygosity is frequent in Turkish population, possibly because of high rate of consanguineus marriages. The MTHFR $1298 \mathrm{~A}>\mathrm{C}$ SNP (homozygous) genotype was found $13.86 \%$ for Turkish and $10.78 \%$ for the Belarusian cohorts. Statistical significance was detected in $\mathrm{C} 677 \mathrm{~T}$ at recessive model and A1298C both recessive and dominant models. As claimed by Jeon et. al. the abberant PAI-1 gene expression may contribute to thrombosis and inflammation, leading to the RPL. The prevalence of genotypes for PAI-I gene were also similar but frequent at Belarusian women; the $4 \mathrm{G}$ allele frequency was 0.513 for the Turkish and 0.550 for the Belarusian cohort (p:0.03) and difference is more significant for recessive model $(\mathrm{p}=0.0019)$. Mutated I allele frequency in ACE I/D gene was different in the comparison of both populations and that difference was also statistically significant. Subrt et al. Were also reported the homozygous PAI-1 (-675) 4G/4G genotype that associated with increased risk of RPL [25].

The FVL mutation profiles from Southern Slavic population were reported by Clark et al. [26]. The current results also show the prevalence of genotypes of $F V L$ G/A in Turkish and Belarusian RPL groups. The mutated A allele frequency in FVL gene was 0.066 for Turkish and 0.011 for the Belarusian groups in the current results. The FVLA/A (homozygous) genotype was found $0.36 \%$ and $0.00 \%$ in Turkish and Belarussian RPL women respectivelly. Mutated A allele frequency was different in the comparison of the both populations and that difference was statistically significant.

Two other thrombophilic factors of FVR2 and FXIII genes were also compared in the presented results. An association with RPL has also been reported for the codon $103 \mathrm{G}>\mathrm{T}$ polymorphism of the FXIII gene by leading to fibrin degradation [27]. Statistically significant difference was also detected in FVR2 G/A SNP in the studied populations in the current results. The prevalence of genotypes of FVR2G/A in Turkish RPL group ( $94.82 \%$ for G/G $4.94 \%$ for G/A and $0.24 \%$ for A/A) and ( $98.29 \%$ for $\mathrm{G} / \mathrm{G} 1.71 \%$ for $\mathrm{G} / \mathrm{A}$ and $0.0 \%$ for $\mathrm{A} / \mathrm{A}$ ) in Belarusian group respectively (Table 6). The A allele frequency was 0.027 for Turkish and 0.009 for the Belarusian groups. The FVR2A/A (homozygous) genotype was found $0.24 \%$ and $0.00 \%$ in Turkish and Belarusian RPL women respectivelly. Mutated A allele frequency was different in the comparison of the both populations and that difference was statistically significant. Increased frequency of mutated Factor XIII103G $>\mathrm{T}$ was also detected in Belarusian RPL cohort in the current results. That difference was also statistically significant when comapred to the Turkish RPL cohort. The prevalence of genotypes for FXIII 103G $>$ T in Turkish RPL group (59.89\% for G/G, 38.37\% for G/T and $1.74 \%$ for $\mathrm{T} / \mathrm{T}$ ) and $(45.00 \%$ for $\mathrm{G} / \mathrm{G}, 45.79 \%$ for $\mathrm{G} / \mathrm{T}$ and $9.21 \%$ for $\mathrm{T} / \mathrm{T})$ in Belarusian group respectively (Table 7 ). The Leucine aminoasid frequency was 0.209 for Turkish and 0.321 for the Belarusian groups. The Factor XIIII03G $>$ T (homozygous) genotype was found $1.74 \%$ and 9.21\% in Turkish and Belarussian RPL women respectivelly. Missense mutated Lecuine frequency was significantly frequent $(5.29$-fold increased) in the Belarusian cohort. The double and triple combined gene mutations profiles were also compared in the current RPL women from Turkish and Belarusian populations. The higest double combined mutations were detected in $A C E+P A I-1$ genes in both RPL cohort. The triple FVR2+ACEI/D+FXIII mutations were totaly the same in both populations. The higest triple combined mutations were detected in FVL+MTHFRA1298C+PAI-1, FVL+MTHFRA1298C+ACE, FVR2+ $A C E+P A I-1$ and FXIII+FVR2+PAI-1 genes respectivelly. The lowest triple combined mutations was detected in FXIII+FII+FVL gene combinations. There are lots of literature findings show mutation frequencies for the thrombophilic genes in health controls in Turkish population [28-30]. The current presented results from Turkish RPL women were remarkable different when compare to the health control individuals that has been published in some reports [28-30]. Current results are the first report on mutation frequencies for the thrombophilic genes in RPL women in Belarusian population. Preliminary ongoing results on health controls from the Belarusian group show remarkable difference (dato not shown) when compare to the presented RPL women from the same population. With an overview to the current study, the thrombophilic gene mutations have a combined risk effect on RPL. The karyotype analyses and other molecular genetic testing of the inherited thrombophilic genes in RPL women with two or more losses may help to understand of risk factors beyond the etiology and may direct interventions, prenatal diagnosis for the couples with pregnancy losses.

In conclusion, retrospectively evaluated results showed similar germ-line prothrombotic gene variations in RPL women in both populations. The FVL and FVR2G/A mutations frequencies were significantly less than Turkish RPL women when compare to the Belarus RPL women. Results also suggest that thrombophilic polymorphisms, either alone or in combination, are major determinants of the development of RPL in both studied Caucasian populations. Based on the current results, evaluation of multiple polymorphisms linked with inherited thrombophilia should be recommended in couples with two or more pregnancy losses.

\section{Authors' contributions}

F.S., IM and A.V.K; acquisition of data, performed the bioinformatical work, analyzed the clinical data and designed the clinical experiments, O.O., F.S, and A.G.; designed the experiments, performed PCR, analyzed the data, N.S., B.K. and A.G.; interpretation of data, performed the statistical analysis, O.O.; supervised the project, wrote and F.S., and I.M.; made the fine redaction of article

All authors read and approved the final manuscript.

\section{References}

1. Regan L, Rai R (2000) Epidemiology and the medical causes of miscarriage. Baillieres Best Pract Res Clin Obstet Gynaecol 14: 839-854. [Crossref]

2. Shahine L, Lathi R (2015) Recurrent pregnancy loss: evaluation and treatment. Obstet Gynecol Clin North Am 42: 117-134. [Crossref]

3. Coccia ME, Rizzello F, Capezzuoli T, Spitaleri M, Riviello C (2015) Recurrent pregnancy losses and gestational age are closely related: an observational cohort study on 759 pregnancy losses. Reprod Sci 22: 556-562. [Crossref]

4. Pluchino N, Drakopoulos P, Wenger JM, Petignat P, Streuli I, et al. (2014) Hormona causes of recurrent pregnancy loss (RPL). Hormones (Athens) 13: 314-322. [Crossref]

5. Farahmand K, Totonchi M, Hashemi M, Reyhani Sabet F, Kalantari H, et al. (2016) Thrombophilic genes alterations as risk factor for recurrent pregnancy loss. J Matern Fetal Neonatal Med 29: 1269-1273. [Crossref]

6. Dutra CG, Fraga LR, Nácul AP, Passos EP, Gonçalves RO, et al. (2014) Lack of association between thrombophilic gene variants and recurrent pregnancy loss. Hum Fertil (Camb) 17: 99-105. [Crossref]

7. Patil R, Ghosh K, Vora S, Shetty S (2015) Inherited and acquired thrombophilia in Indian women experiencing unexplained recurrent pregnancy loss. Blood Cells Mol 
Silan F (2016) Comparison of the thrombophilic gene polymorphisms and recurrent pregnancy loss: Results on combined gene effect of FV Leiden, FVR2, FXIII, MTHFR(A1298C and C677T), PAI-1 4G/5G and ACE I/D genes in RPL Women from Minsk/Belarus and Canakkale - Sivas/Turkey

\section{Dis 55: 200-205. [Crossref]}

8. Schleussner E, Kamin G, Seliger G, Rogenhofer N, Ebner S, et al. (2015) Lowmolecular-weight heparin for women with unexplained recurrent pregnancy loss: multicenter trial with a minimization randomization scheme. Ann Intern Med 162: 601609. [Crossref]

9. Hyde KJ, Schust DJ (2015) Genetic considerations in recurrent pregnancy loss. Cold Spring Harb Perspect Med 5: a023119. [Crossref]

10. Khankin EV, Royle C, Karumanchi SA (2010) Placental vasculature in health and disease. Semin Thromb Hemost 36: 309-320. [Crossref]

11. Yousefian E, Kardi MT, Allahveisi A (2014) Methylenetetrahydrofolate Reductase C677T and A1298C Polymorphism in Iranian women with idiopathic recurrent pregnancy losses. Iran Red Crescent Med J 16: e16763. [Crossref]

12. Kim JJ, Choi YM, Lee SK, Yang KM, Paik EC, et al. (2014) The PAI-1 4G/5G and ACE I/D polymorphisms and risk of recurrent pregnancy loss: a case-control study. $\mathrm{Am}$ J Reprod Immunol 72: 571-576. [Crossref]

13. Ali N1, Bhatti FA, Khan SA (2014) Frequency of hereditary thrombophilia in women with recurrent pregnancy loss in Northern Pakistan. J Obstet Gynaecol Res 40: 15611566. [Crossref]

14. Isaoglu U, Ulug P, Delibas IB, Yilmaz M, Kumtepe Y, et al. (2014) The association between inherited thrombophilia and recurrent pregnancy loss in Turkish women. Clin Exp Obstet Gynecol 41: 177-181. [Crossref]

15. Parand A, Zolghadri J, Nezam M, Afrasiabi A, Haghpanah S, et al. (2013) Inherited thrombophilia and recurrent pregnancy loss. Iran Red Crescent Med J 15: e13708. [Crossref]

16. Sarig G, Younis JS, Hoffman R, Lanir N, Blumenfeld Z, et al. (2002) Thrombophilia is common in women with idiopathic pregnancy loss and is associated with late pregnancy wastage. Fertil Steril 77: 342-347. [Crossref]

17. Carp H, Salomon O, Seidman D, Dardik R, Rosenberg N, et al. (2002) Prevalence of genetic markers for thrombophilia in recurrent pregnancy loss. Hum Reprod 17: 16331637. [Crossref]

18. Dizon-Townson D, Meline L, Nelson L, Varner M, Ward K (1997) Fetal carriers of the factor V Leiden mutation are prone to miscarriage and placental infarction. Am J Obste Gynecol 177: 402-405. [Crossref]

19. Sottilotta G, Oriana V, Latella C, Luise F, Piromalli A, et al. (2006) Genetic prothrombotic risk factors in women with unexplained pregnancy loss. Thromb Res 117: 681-684. [Crossref]

20. Yousefian E, Kardi MT, Allahveisi A (2014) Methylenetetrahydrofolate Reductas C677T and A1298C Polymorphism in Iranian women with idiopathic recurren pregnancy losses. Iran Red Crescent Med J 16: e16763. [Crossref]

21. Kim JJ, Choi YM, Lee SK, Yang KM, Paik EC, et al. (2014) The PAI-1 4G/5G and ACE I/D polymorphisms and risk of recurrent pregnancy loss: a case-control study. $\mathrm{Am}$ J Reprod Immunol 72: 571-576. [Crossref]

22. Qiao Y, Wen J, Tang F, Martell S, Shomer N, et al. (2016) Whole exome sequencing in recurrent early pregnancy loss. Mol Hum Reprod 22: 364-372. [Crossref]

23. Naushad SM, Krishnaprasad C, Devi AR (2014) Adaptive developmental plasticity in methylene tetrahydrofolate reductase (MTHFR) C677T polymorphism limits its frequency in South Indians. Mol Biol Rep 41: 3045-3050. [Crossref]

24. Jeon YJ, Kim YR, Lee BE, Choi YS, Kim JH, et al. (2013) Genetic association of five plasminogen activator inhibitor-1 (PAI-1) polymorphisms and idiopathic recurrent pregnancy loss in Korean women. Thromb Haemost 110: 742-750. [Crossref]

25. Subrt I, Ulcova-Gallova Z, Cerna M, Hejnalova M, Slovanova J, et al. (2013) Recurren pregnancy loss, plasminogen activator inhibitor-1 (-675) $4 \mathrm{G} / 5 \mathrm{G}$ polymorphism and antiphospholipid antibodies in Czech women. Am J Reprod Immunol 70: 54-58. [Crossref]

26. Clark JS, Adler G, Salkic NN, Ciechanowicz A (2013) Allele frequency distribution of $1691 \mathrm{G}>\mathrm{A}$ F5 (which confers Factor V Leiden) across Europe, including Slavic populations. J Appl Genet 54: 441-446. [Crossref]

27. Ariëns RA, Philippou H, Nagaswami C, Weisel JW, Lane DA, et al. (2000) The facto XIII V34L polymorphism accelerates thrombin activation of factor XIII and affects cross-linked fibrin structure. Blood 96: 988-995. [Crossref]

28. Isaoglu U, Ulug P, Delibas IB, Yilmaz M, Kumtepe Y, et al. (2014) The association between inherited thrombophilia and recurrent pregnancy loss in Turkish women. Clin Exp Obstet Gynecol 41: 177-181. [Crossref]

29. Bagheri M, Abdi Rad I, Omrani MD, Nanbaksh F (2010) Polymorphisms of the angiotensin converting enzyme gene in Iranian Azeri Turkish women with unexplained recurrent pregnancy loss. Hum Fertil (Camb) 13: 79-82. [Crossref]

30. Yenicesu GI, Cetin M, Ozdemir O, Cetin A, Ozen F, et al. (2010) A prospective casecontrol study analyzes 12 thrombophilic gene mutations in Turkish couples with recurrent pregnancy loss. Am J Reprod Immunol 63: 126-136. [Crossref]

Copyright: (C2016 Silan F. This is an open-access article distributed under the terms of the Creative Commons Attribution License, which permits unrestricted use, distribution, and reproduction in any medium, provided the original author and source are credited. 